\title{
Investigation of the Properties and Effects of Salvia Officinalis L. on the Viability, Steroidogenesis and Reactive Oxygen Species (ROS) Production in TM3 Leydig Cells in Vitro
}

\author{
Tomas JAMBOR ${ }^{1}$, Julius ARVAY ${ }^{2}$, Eva IVANISOVA ${ }^{3}$, Eva TVRDA ${ }^{4}$, Anton KOVACIK ${ }^{4}$, \\ Hana GREIFOVA ${ }^{4}$, Norbert LUKAC ${ }^{4}$
}

${ }^{1}$ BioFood Center, Faculty of Biotechnology and Food Sciences, Slovak University of Agriculture in Nitra, Nitra, Slovak Republic, ${ }^{2}$ Department of Chemistry, Faculty of Biotechnology and Food Sciences, Slovak University of Agriculture in Nitra, Nitra, Slovak Republic, ${ }^{3}$ Department of Technology and Quality of Plant Products, Faculty of Biotechnology and Food Sciences, Slovak University of Agriculture in Nitra, Nitra, Slovak Republic, ${ }^{4}$ Department of Animal Physiology, Faculty of Biotechnology and Food Sciences, Slovak University of Agriculture in Nitra, Nitra, Slovak Republic

Received March 3, 2020

Accepted May 6, 2020

Epub Ahead of Print June 25, 2020

\section{Summary}

The aim of our study was to reveal the in vitro effects of Salvia officinalis L. $(37.5,75,150,200,250,300$ and $600 \mu \mathrm{g} / \mathrm{ml})$ extract on the TM3 Leydig cell viability, membrane integrity, steroidogenesis and reactive oxygen species production after $24 \mathrm{~h}$ and $48 \mathrm{~h}$ cultivation. For the present study, the extract prepared from Salvia officinalis L. leaves was analyzed by high performance liquid chromatography (HPLC) for selected flavonoids and phenolic acids followed by a determination of its free radicals scavenging activity (DPPH). Furthermore, Leydig cell viability was assessed by the mitochondrial toxicity assay (MTT), while the membrane integrity was evaluated by 5- carboxyfluorescein diacetate-acetoxymethyl ester (5-CFDAAM). The level of steroid hormones was performed by enzymelinked immunosorbent assay (ELISA) from the culture media, while the superoxide radical generation was measured by the nitroblue tetrazolium chloride (NBT) assay. The results show that experimental concentrations did not damage the cell membrane integrity and viability when present at below $300 \mu \mathrm{g} / \mathrm{ml}$, it was only at $600 \mu \mathrm{g} / \mathrm{ml}$ that a significant $(P<0.05)$ cell viability decline was observed after a $48 \mathrm{~h}$ cultivation. A significant $(P<0.05)$ stimulation of testosterone secretion was recorded at $250 \mu \mathrm{g} / \mathrm{ml}$ for $24 \mathrm{~h}$, while the prolonged cultivation time significantly $(P<0.05)$ increased the testosterone and progesterone production at $150,200,250$ and $300 \mu \mathrm{g} / \mathrm{ml}$. Furthermore, none of the selected doses exhibited significant ROS-promoting effects however, the highest dose of Salvia initiated the free radical scavenging activity in cultured mice Leydig cells.

\section{Key words}

Salvia officinalis L. • Leydig cells • Viability • Steroidogenesis • Reactive oxygen species

\section{Corresponding author}

Tomas Jambor, Department of Animal Physiology, Faculty of Biotechnology and Food Sciences, BioFood Center, Slovak University of Agriculture in Nitra, Tr. A. Hlinku 2, 94976 Nitra, Slovak Republic. E-mail: tomasjambor1@gmail.com

\section{Introduction}

There is overwhelming evidence about the potential ability of heavy metals, endocrine disruptors and other environmental pollutants to affect the health status of an individual. In addition, inadequate nutrition and current lifestyle are crucial factors responsible for reproductive disturbance (Jambor et al. 2018, Kovacik et al. 2018, Saha et al. 2019). Steroidogenesis running in Leydig cells converts cholesterol into various steroid hormones through the steroidogenic enzymes (P450scc, 
$3 \beta$-HSD, 17 $\beta$-HSD) and the steroidogenic acute regulatory protein (StAR) under the control of the luteinizing hormone (LH) (Wang et al. 2017). The levels of steroid hormones depend on the number of cells and the steroid enzyme capacity to convert cholesterol. An exceptionally negative impact from the current environment may irreversibly inhibit the metabolic activity and steroidogenic functions of Leydig cells as well as decrease the semen quality or epididymal weight, increase the incidence of testicular cancer and subsequently affect the sexual behavior (Sultan et al. 2001, Singh and Lin, 2012, Halo et al. 2019). Therefore, we attempt to point out natural sources which are able to effectively reverse this negative worldwide situation. Currently, medicinal plants are recognized as an alternative source of efficient biologically active compounds as opposed to synthetic medications and are used as primary health care remedies. Likewise, a great variety of them has been used for the enhancement of male fertility (Tohamy et al. 2012, Fattahi and Vaseghi 2015). Salvia officinalis L. commonly known as sage is extremely rich in polyphenolic compounds, which are thought to be responsible for an abundant antioxidative potential. Salvia consists of a complex mixture of monoterpenes, diterpene, sesquiterpenes, flavonoids and phenolic acids. Together with another phytoconstituents such as cineol, borneol, rosmarinic acid, chlorogenic acid, salvianolic acid or vitamin $\mathrm{C}$ and $\mathrm{E}$, sage represents the best way to protect individuals against different types of detrimental effects caused by xenobiotics (Kosar et al. 2010, Rahte et al. 2013). It has been confirmed that Salvia products exhibit beneficial anti-inflammatory, antihyperglycemic, spasmolytic, antiseptic or hepatoprotective activities. S. officinalis L. is useful for the treatment of profuse perspiration, depression, anxiety as well as menopausal and sterility complications. Furthermore, some experimental studies indicate that molecules contained in Salvia scavenge free radical thereby minimize the damaging effects of oxidative insults (Esmaeili et al. 2009, Rahte et al. 2013). Overleaf, there is very limited information about the potential in vitro effects of Salvia on the Leydig cells function. There exists a strong conviction that bioactive phytoconstituents in Salvia may affect the production of steroid hormones, metabolic activity and reactive oxygen species generation (ROS), and further initiate changes in the reproductive health (Fattahi and Vaseghi 2015, Tvrdá et al. 2017). The present in vitro study aims to evaluate the potential effects of the ethanolic extract from
S. officinalis L. $(37.5-600 \mu \mathrm{g} / \mathrm{ml})$ on the TM3 Leydig cell line during different time periods. The experiments had in view to determine whether the use of the Salvia extract of known composition exhibits any positive effects on the mitochondrial activity or membrane integrity, as well as sexual hormone release and reactive oxygen species production in mice Leydig cells.

\section{Material and Methods}

\section{Plant material and extract preparation}

The leaves from Salvia officinalis L. were harvested in the Botanical Garden at the Slovak University of Agriculture in Nitra. After freeze-dried $\left(-80{ }^{\circ} \mathrm{C}\right)$, the plant material was crushed and weighed. An aliquot of the plant material was soaked in $96 \%$ ethanol (p.a. CentralChem, Bratislava, Slovak republic) for two weeks. In order to avoid the degradation of bioactive substances, the extraction was realized in the dark and at laboratory temperature. Subsequently, the ethanolic plant extract was subjected to evaporation (Stuart RE300DB rotary evaporator, Bibby Scientific Limited, United Kingdom) under reduced pressure (vacuum pump KNF N838.1.2KT.45.18, KNF, Germany) and elevated temperature $40{ }^{\circ} \mathrm{C}$ in order to remove any residual ethanol. The crude plant extract was dissolved in a standard organic solvent DMSO (Dimethyl sulfoxide, Sigma Aldrich, St. Louis, USA) to equal $100.4 \mathrm{mg} / \mathrm{ml}$ as a stock solution.

Quantitative high-performance liquid chromatography (HPLC-DAD) analysis of the extract

All analytical standards such as methanol (HPLC grade), acetonitrile (gradient HPLC grade) and phosphoric acid (ACS grade) were purchased from Sigma Aldrich (St. Louis, USA). Before to HPLC analysis, the plant extract was filtered through a syringe filters Q-Max (0.22 $\mu \mathrm{m}, 25 \mathrm{~mm}$, PVDF - Frisenette ApS, Knebel, Denmark) into the HPLC vials with PTFE septum. Standard solutions were dissolved in $10 \mathrm{ml}$ of methanol and homogenised. Subsequently, the samples were extracted using $20 \mathrm{ml}$ of $80 \%(\mathrm{v} / \mathrm{v})$ methanol any horizontal shaker (Unimax 2010, Heidolph Instrument, GmbH, Germany). After filtration (Munktell No 390, Munktell \& Filtrac, Germany), the samples were stored in vial tubes. The extracts and standard solutions were filtered through the Q-Max syringe filter and then injected. The high-performance liquid chromatograph (Agilent 1260 Infinity HPLC Technologies, GmbH, 
Waldbronn, Germany) with quaternary solvent manager coupled with degasser, sampler manager, Diode Array Detector and column manager were used to analysis of phenolic acids and flavonoids in the leaves extract of Salvia officinalis L. HPLC analyses were performed on a Purosphere reverse phase C18 column (4 mm x $250 \mathrm{~mm}$ x $5 \mathrm{~mm}$, Merck, KGaD, Darmstadt, Germany). The gradient system with a mobile phase of $0.1 \%$ phosphoric acid in deionized water and gradient grade acetonitrile at a flow rate of $0.60 \mathrm{ml} / \mathrm{min}$ and the injection volume was $3 \mu \mathrm{l}$. The gradient elution was as follows: $0-1 \mathrm{~min}$ isocratic elution $(90 \% \mathrm{C}$ and $10 \% \mathrm{D}), 1-6$ min linear gradient elution ( $85 \% \mathrm{C}$ and $15 \% \mathrm{D}), 6-12 \min (80 \% \mathrm{C}$ and $20 \% \mathrm{D}), 12-20 \mathrm{~min}(30 \% \mathrm{C}$ and $70 \% \mathrm{D})$ and $20-25 \min (30 \% \mathrm{C}$ and $70 \% \mathrm{D})$. The post-run was set at 3 min. Column thermostat was set to $30{ }^{\circ} \mathrm{C}$ and the sample was kept at $6{ }^{\circ} \mathrm{C}$ in the sampler manager. Data were collected and processed using Agilent Open Lab Chem Station software for LC 3D systems (Lukšič et al. 2016).

\section{DPPH radical scavenging assay}

Free radical scavenging activity of the Salvia officinalis L. was measured using the 2,2-difenyl-1picrylhydrazyl (DPPH) method described by SanchézMoréno et al. (1998). An amount of $0.4 \mathrm{ml}$ Salvia extract was added to $3.6 \mathrm{ml}$ of DPPH solution (0.025 g DPPH in $100 \mathrm{ml}$ ethanol, Sigma Aldrich, St. Louis, USA). The absorbance of the reaction mixture was determined using the Jenway 6405 UV/VIS spectrophotometer (Fisher Scientific, Leicestershire, United Kingdom) at wavelength $515 \mathrm{~nm}$. The free radical scavenging activity was expressed as percentage of DPPH inhibition by the following formula:

$$
\% \text { of inhibition }=[(\mathrm{Ac}-\mathrm{As}) /(\mathrm{Ac})] \times 100
$$

where: Ac is the absorbance of DPPH alone and As is the absorbance of DPPH along with sample.

\section{Estimation of total phenolic content}

Total polyphenolic content of Salvia officinalis L. extract was evaluated according to Singleton and Rossi (1965) with slight modifications and described as the Folin-Ciocalteu method. One hundred $\mu 1$ of sample were mixed with the same volume of the FolinCiocalteu reagent (Sigma Aldrich, St. Louis, USA), 1000 $\mu 1$ of $20 \%(\mathrm{w} / \mathrm{v})$ sodium carbonate (Sigma Aldrich, St. Louis, USA), and $8800 \mu 1$ of distilled water. After $30 \mathrm{~min}$ in darkness the absorbance was measured at $700 \mathrm{~nm}$ wavelength using the Jenway 6405 UV/VIS spectrophotometer (Fisher Scientific, Leicestershire, United Kingdom). The total concentration of phenols was calculated using the standard curve, gallic acid was used as the standard and the results were expressed as mg of gallic acid equivalents (GAE) per kg of dry matter.

\section{Cell culture}

The TM3 Leydig cell line, non-tumorogenic cells derived from mouse testis strain BALB/c nu/+ were purchased from the American type Culture Collection (ATCC \#CRL-1714, Manassas, VA, USA) as a suitable model for our in vitro study. Cells were cultured in Dulbecco's Modified Eagle's Medium/Nutrient Mixture (Ham's) F12 with HEPEs and NaHCO3 (DMEM/F12, Sigma Aldrich, St. Louis, USA) supplemented with $5 \%$ horse serum (HS, Gibco-Life Technologies, New Zealand), $2.5 \%$ fetal bovine serum (FBS, BiochromAG, Berlin, Germany), $2.5 \mathrm{mM}$ L-glutamine (Sigma Aldrich, St. Louis, USA) and $1 \%$ penicillin/streptomycin solution (Sigma Aldrich, St. Louis, USA). TM3 cells were maintained at $37{ }^{\circ} \mathrm{C}$ under a humidified atmosphere of $95 \%$ air and $5 \% \mathrm{CO}_{2}$. The Leydig cells density was determined using a haemocytometer, adjusted with culture medium to a final concentration of $2-4 \mathrm{x}$ $10^{3}$ cells/well. The cells were seeded into $96-$ well plate and pre-cultured for $24 \mathrm{~h}$. Afterwards, the medium was changed to include different experimental concentrations of ethanolic extract Salvia officinalis L. at 37.5, 75, 150, 200, 250, 300 and $600 \mu \mathrm{g} / \mathrm{ml}$. The TM3 cells remained in culture during $24 \mathrm{~h}$ and $48 \mathrm{~h}$ respectively (Fig. 1).

\section{Cell viability (MTT) assay}

To assess the effect of the Salvia officinalis L. experimental doses $(37.5-600 \mu \mathrm{g} / \mathrm{ml})$ on the TM3 Leydig cells viability after $24 \mathrm{~h}$ and $48 \mathrm{~h}$ exposure, mitochondrial toxicity assay (MTT, 3-4,5-dietyltiazol-2yl)-2,5-diphenyltetratzolium bromide) was exploited. This colorimetric assay measures the reduction of soluble yellow tetrazolium salt (Sigma Aldrich, St. Louis, USA) to water-insoluble blue formazan crystals by mitochondrial succinate dehydrogenase activity in living cells (Mosmann, 1983). Following respective exposure, the culture medium was removed, and the cells were treated with $1 \mathrm{mg} / \mathrm{ml}$ of tetrazolium salt during $3 \mathrm{~h}$ at $37^{\circ} \mathrm{C}$ under a humidified atmosphere of $95 \%$ air and $5 \% \mathrm{CO}_{2}$ (Fig. 2). Afterward, the formed formazan crystals were dissolved by DMSO (Sigma Aldrich, 

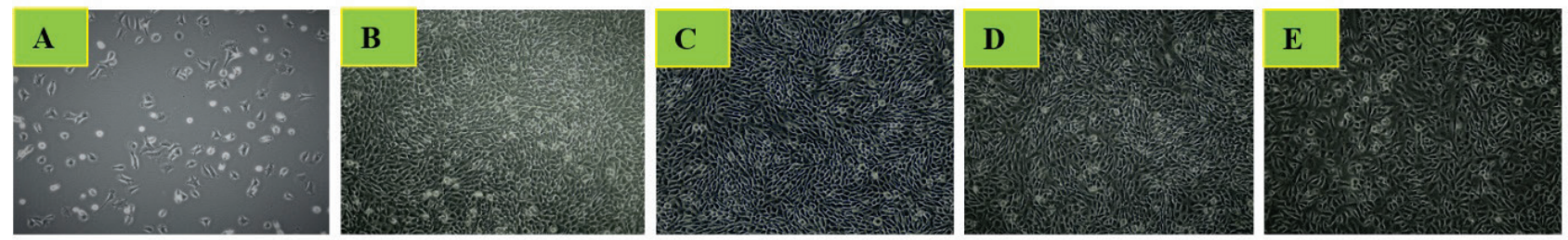

Fig. 1. TM3 Leydig cells growing in different experimental concentrations of Salvia officinalis L. during $24 \mathrm{~h}$ in vitro cultivation. A - after subculturing, B - untreated (control) cells, C - $150 \mu \mathrm{g} / \mathrm{ml}, \mathbf{D}-300 \mu \mathrm{g} / \mathrm{ml}, \mathbf{E}-600 \mu \mathrm{g} / \mathrm{ml}$. The cells were observed under a phase-contrast microscope (Leica Microsystems CMS GmbH, Wetzlar, Germany), magnification 200x. (colorless)
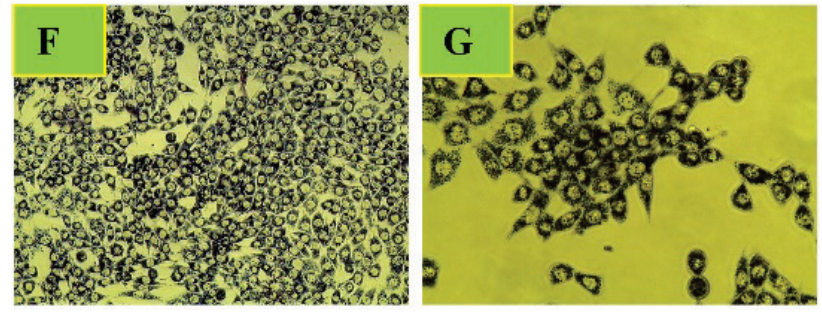

Fig. 2. Formazan crystals formed after $3 \mathrm{~h}$ incubation with yellow tetrazolium salt. Formazan deposits indicate mitochondrial succinate dehydrogenase activity in living cells. The cells were observed under a phase-contrast microscope (Leica Microsystems CMS GmbH, Wetzlar, Germany), magnification: F - 200x, G - 400x, (colorless)

St. Louis, USA), gently shaking for $20 \mathrm{~min}$ and read by an ELISA reader (Multiscan FC, ThermoFisher Scientific, Vantaa, Finland) at $570 \mathrm{~nm}$ against $620 \mathrm{~nm}$ wavelengths. Cells from four independent experiments were analyzed for each treatment. All data were expressed in percentage of control (non-treated cells) group.

\section{Cell membrane integrity (CFDA-AM) assay}

The loosing of cell membrane integrity was assessed directly in the cell culture wells using the fluorescent probe 5-carboxyfluorescein diacetate, acetoxymethyl ester (CFDA-AM, ThermoFisher Scientific, Invitrogen, Vantaa, Finland) described by Schreer et al. (2005) with a slight modification. In brief, cell culture media supplemented with Salvia officinalis L. (37.5-600 $\mu \mathrm{g} / \mathrm{ml})$ were removed from the plates after $24 \mathrm{~h}$ and $48 \mathrm{~h}$ exposure. Subsequently, confluent monolayers of TM3 cells were cultured in the presence of $4 \mu \mathrm{M}$ CFDA-AM for $30 \mathrm{~min}$ under a humidified atmosphere of $95 \%$ air and $5 \% \mathrm{CO}_{2}$. The concentrations of the fluorescent metabolites of CFDA-AM were measured using the wavelength of 485-530 nm (excitation/emission) respectively. Fluorescence was measured as arbitrary units and reading for the wells without cells were subtracted from those for the experimental wells to account for background fluorescence. The experimental data were expressed as percentage of non-treated cells (control group).

\section{Enzyme-linked immunosorbent assay (ELISA) for} detecting steroid hormones

To examine the progesterone and testosterone secretion after $24 \mathrm{~h}$ and $48 \mathrm{~h}$ exposition, TM3 cells were cultured in the presence of experimental doses of Salvia officinalis L. mentioned above. After in vitro incubation, the cell culture media was removed from each experimental well and stored in Eppendorf tubes at $-20{ }^{\circ} \mathrm{C}$ until assay. The production of steroid hormones was determined by enzyme-linked immunosorbent assay (ELISA). The ELISA kits were purchased from Dialab (testosterone, Cat. \#K00234, progesterone, Cat. \#K00225, Austria) and the procedure was carried out according to the manufacture instructions. The sensitivities for steroid hormones are presented in Table 1. The absorbance was measured at $450 \mathrm{~nm}$ wavelength by an ELISA reader (Multiscan FC, ThermoFisher Scientific, Vantaa, Finland). The results are expressed as percentage of the control (non-treated) group.

\section{Nitroblue-tetrazolium reduction (NBT) assay}

The superoxide radicals produced in TM3 Leydig cell line were evaluated by the nitrobluetetrazolium (NBT) assay after respective treatment by Salvia officinalis L. (37.5-600 $\mu \mathrm{g} / \mathrm{ml})$ for $24 \mathrm{~h}$ and $48 \mathrm{~h}$. This colorimetric assay is conducted by evaluating cells containing blue formazan deposits. They are formed by reduction of the membrane permeable yellow colored nitroblue-tetrazolium chloride (2,2'bis(4-nitro-phenyl)5,5'-diphenyl-3,3' -dimethoxy-4,4'-diphenylene) diterazolium chloride (Sigma Aldrich, St. Louis, USA) and superoxide radicals (Choi et al. 2006). After in vitro cultivation, the culture media were removed and TM3 Leydig cells were further incubated in the presence of $100 \mu \mathrm{l} /$ well NBT working reagent ( $1 \mathrm{mg}$ NBT per $1 \mathrm{ml}$ culture media dissolved in DMSO) under a humidified 
Table 1. Intra-assay, inter-assay variability and sensitiveness for the selected steroid hormones

\begin{tabular}{lccc}
\hline Hormone & Intra-assay variability (\%) & Inter-assay variability (\%) & Sensitivity \\
\hline Progesterone & $\leq 4.0$ & $\leq 9.3$ & $0.05 \mathrm{ng} / \mathrm{ml}$ \\
Testosterone & $\leq 7.0$ & $\leq 8.3$ & $0.10 \mathrm{ng} / \mathrm{ml}$ \\
\hline
\end{tabular}

atmosphere of $95 \%$ air and $5 \% \mathrm{CO}_{2}$ for $3 \mathrm{~h}$. Afterwards, the formazan products were solubilized in $100 \mu \mathrm{l} /$ well of $2 \mathrm{M} \mathrm{KOH} \mathrm{(potassium} \mathrm{hydroxide,} \mathrm{p.a.} \mathrm{CentralChem,}$ Bratislava, Slovak Republic). The resulting colour reaction was measured spectrophotometrically at wavelength of $620 \mathrm{~nm}$ against $570 \mathrm{~nm}$ as reference by an ELISA reader (Multiscan FC, ThermoFisher Scientific, Vantaa, Finland). All experimental data were expressed in percentage of control (optical density of formazan from cells not exposed to tested extract).

\section{Statistical analysis}

The obtained data were statistically analyzed using the GraphPad Prism 5.0 (GraphPad Software Incorporated, San Diego California, USA). One-way analysis of variance (ANOVA) followed by Dunnett's multiple comparison test was used for statistical evaluations. Results were expressed as the mean \pm standard deviation (S.D). All experiments were repeated at least three times. Each experimental group was represented by six culture wells of the cells. Statistical differences were expressed at a significance of $P<0.05$.

\section{Results}

\section{Chemical constituents and antioxidant properties}

HPLC-DAD analysis was chosen as a suitable method for the investigation of the quality and quantity of flavonoids and phenolic acids. We identified bioactive substances on the basis of the retention time and the UV spectra chromatogram pattern. Cynaroside $(41.9 \pm 7.4 \mathrm{mg} / \mathrm{kg})$ prevailed amongst the analyzed flavonoids, followed by rutin $(39.1 \pm 5.2 \mathrm{mg} / \mathrm{kg})$, kaempferol $(38.0 \pm 7.0 \mathrm{mg} / \mathrm{kg})$ and apigenin $(28.3 \pm 4.0$ $\mathrm{mg} / \mathrm{kg})$. Except these, daidzein $(17.3 \pm 1.9 \mathrm{mg} / \mathrm{kg})$, quercetin $(14.6 \pm 3.0 \mathrm{mg} / \mathrm{kg})$, vitexin $(4.4 \pm 0.9 \mathrm{mg} / \mathrm{kg})$ and resveratrol $(2.2 \pm 0.2 \mathrm{mg} / \mathrm{kg})$ were identified as well. Overleaf, rosmarinic acid $(257.8 \pm 30.0 \mathrm{mg} / \mathrm{kg})$ was identified as the predominant phenolic acid in the leaves of Salvia officinalis L. extract. We also detected trans-caffeic acid $(58.6 \pm 7.2 \mathrm{mg} / \mathrm{kg})$, neo-chlorogenic acid $(55.8 \pm 5.0 \mathrm{mg} / \mathrm{kg})$, trans-coumaric acid $(54.5 \pm 6.2 \mathrm{mg} / \mathrm{kg})$ as well as chlorogenic acid $(53.3 \pm 4.9 \mathrm{mg} / \mathrm{kg})$. The total content of phenolic acids was predominantly represented by trans-sinapic acid $(12.4 \pm 1.0 \mathrm{mg} / \mathrm{kg})$ and ferulic acid $(11.2 \pm 0.9 \mathrm{mg} / \mathrm{kg})$. In the present in vitro study, we showed that the free radical scavenging activity of Salvia officinalis L. extract from leaves determined by the DPPH method was at $90.07 \pm 4.01 \%$ inhibition of DPPH level. The total phenolic content determined by the FolinCiocalteu method was set at $7855.68 \pm 59.92 \mathrm{mg}$ of gallic acid per $\mathrm{kg}$.

\section{Effects of Salvia officinalis L. on TM3 cell viability}

Exposure of TM3 mice Leydig cells to various doses of Salvia officinalis L. (from 37.5 to $600 \mu \mathrm{g} / \mathrm{ml}$ ) after $24 \mathrm{~h}$ and $48 \mathrm{~h}$ cultivation was evaluated with respect to cell viability. The results have revealed that the viability of the treated cells was not significantly $(P>0.05)$ affected during $24 \mathrm{~h}$ exposure. A moderate increase was recorded up to $200 \mu \mathrm{g} / \mathrm{ml}(110.5 \pm 9.1 \%)$ with a subsequent decrease at $600 \mu \mathrm{g} / \mathrm{ml}(91.3 \pm 5.2 \%)$ when compared to the control group. As seen in Fig. 3a. none of the selected concentrations had a cytotoxic effect. To further explore the cytotoxicity, the mitochondrial toxicity assay was carried out for the $48 \mathrm{~h}$ cultivation. The viability of TM3 Leydig cells progressively increased with a significant $(P<0.05)$ level at $200 \mu \mathrm{g} / \mathrm{ml}$ $(117.4 \pm 5.3 \%)$. In case of higher doses of Salvia officinalis L. a gradual decline was recorded at 250 and $300 \mu \mathrm{g} / \mathrm{ml}$ with significant $(P<0.05)$ effects at $600 \mu \mathrm{g} / \mathrm{ml}$ (Fig. 3b.). All experimental doses were compared to the control, without treatment $(100 \pm 5.9 \%)$. The presented data suggest that higher concentrations of Salvia officinalis L. may decrease the cell viability in a doseand time-dependent manner.

Effects of Salvia officinalis L. TM3 cell membrane integrity

Mice Leydig cell line TM3 was treated by different concentrations of Salvia officinalis L. during $24 \mathrm{~h}$ and $48 \mathrm{~h}$ cultivation in vitro. As presented in Figure 4a., the cell membrane integrity was not significantly $(P>0.05)$ affected in the whole applied range of 

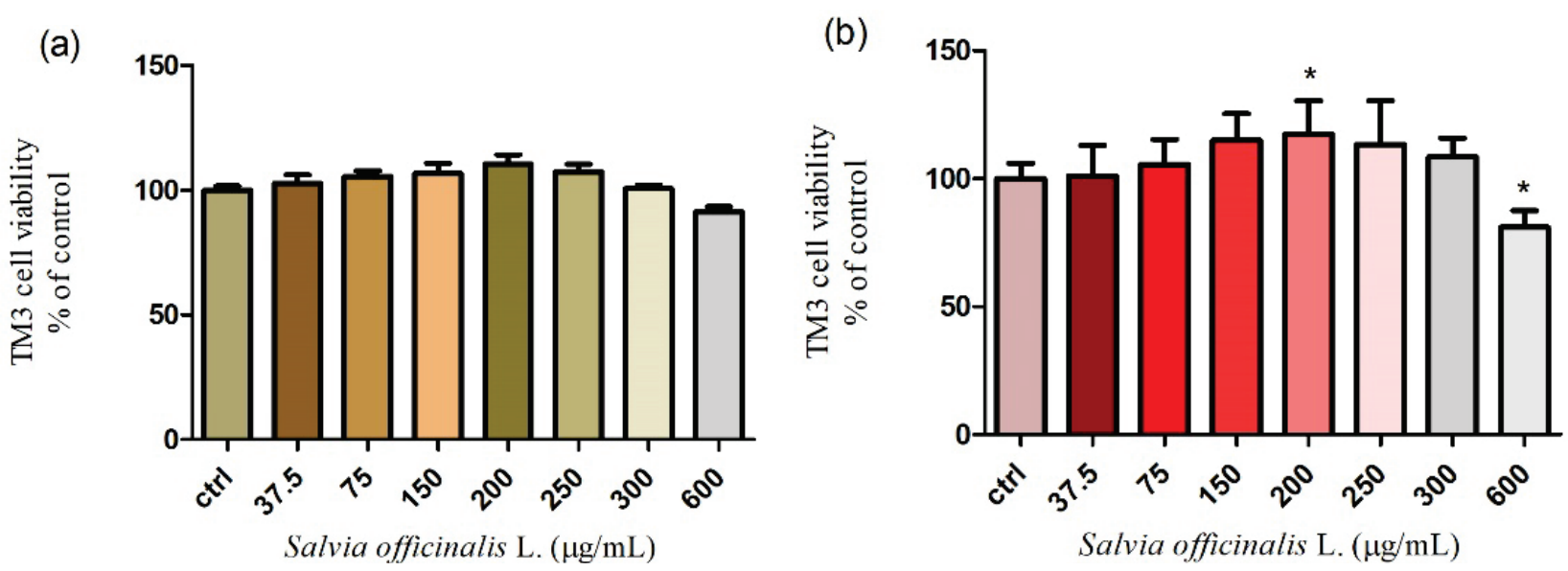

Fig. 3. Cell viability of TM3 Leydig cells treated with different concentrations of Salvia officinalis L. for (a) $24 \mathrm{~h}$ and (b) $48 \mathrm{~h}$ cultivation. Abbreviations: ctrl - control group. Each bar represents the mean ( \pm S.D.) viability \% of control (untreated) and treated groups. Data were obtained from four $(n=4)$ independent experiments. The level of significance was set at $*(P<0.05)$. Statistical differences between the values of control experimental groups is indicated by an asterisk. (colorless)

(a)

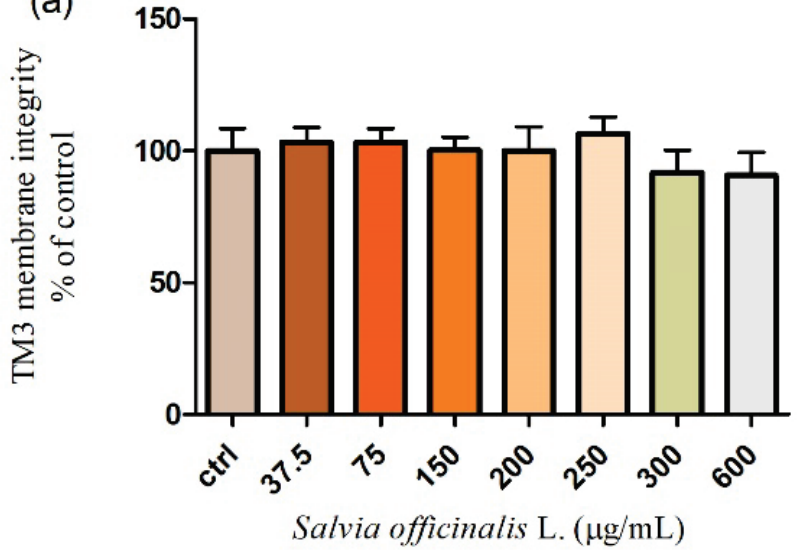

(b)

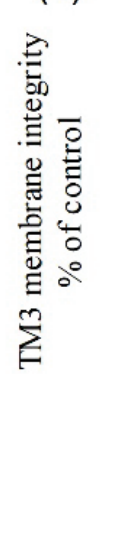

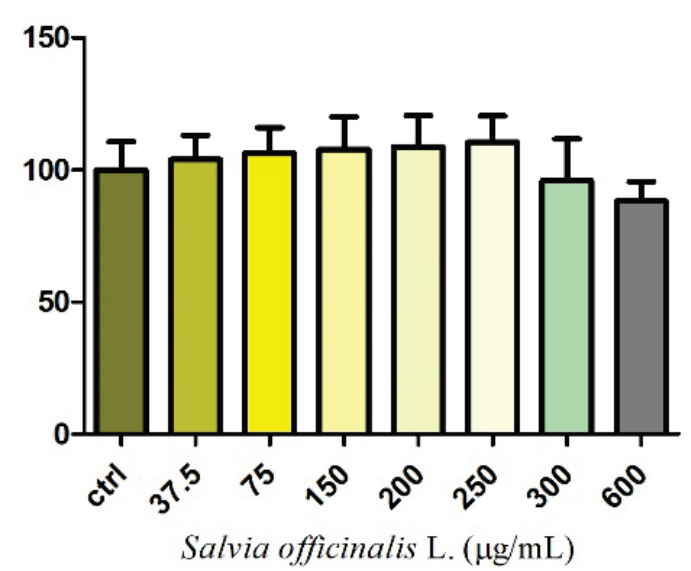

Fig. 4. Membrane integrity of TM3 Leydig cells treated with different concentrations of Salvia officinalis L. for (a) $24 \mathrm{~h}$ and (b) $48 \mathrm{~h}$ cultivation. Abbreviations: ctrl - control group. Each bar represents the mean ( \pm S.D.) membrane integrity \% of control (untreated) and treated groups. Data were obtained from four $(n=4)$ independent experiments. The level of significance was set at $*(P<0.05)$. Statistical differences between the values of control experimental groups is indicated by an asterisk. (colorless)

concentrations $(37.5-600 \mu \mathrm{g} / \mathrm{ml})$ of the extract after $24 \mathrm{~h}$ treatment when compared to the control group $(100 \pm 7.0 \%)$. An extended time of cultivation with higher experimental concentrations (300 and $600 \mu \mathrm{g} / \mathrm{ml}$ ) caused a moderate decline in the membrane integrity of Leydig cells. The results shown in Figure 4b. illustrate that the highest dose of Salvia officinalis L. $(600 \mu \mathrm{g} / \mathrm{ml})$ immediately decreased $(88.1 \pm 7.3 \%)$ this parameter without significant changes $(P>0.05)$. All experimental groups were compared to the control group (100 $\pm 4.3 \%)$.

\section{Assessment of steroid hormone production}

TM3 Leydig cells were cultured in media supplemented with increasing doses of Salvia officinalis L. (37.5 - $600 \mu \mathrm{g} / \mathrm{ml})$ for $24 \mathrm{~h}$ and $48 \mathrm{~h}$. A slight increase of the progesterone production was observed in case of all tested concentrations of Salvia after a $24 \mathrm{~h}$ treatment. The highest stimulating effect, but no significant $(P>0.05)$ was confirmed at $300 \mu \mathrm{g} / \mathrm{ml}(108.9 \pm 5.0 \%)$ when the mean values of the hormone secretion fluctuated between $100.0 \pm 4.1 \%$ in the control group $(3.38 \mathrm{ng} / \mathrm{ml})$ and $108.9 \pm 5.0 \%$ in the experimental group exposed to $300 \mu \mathrm{g} / \mathrm{ml}$ (3.68 ng/ml) (Fig. 5a). Figure $5 \mathrm{~b}$ presents a dose-dependent growth in the progesterone secretion after a $48 \mathrm{~h}$ cultivation. According to our results both of experimental concentrations (150 and $200 \mu \mathrm{g} / \mathrm{ml})$ significantly $(P<0.05)$ increased the steroid hormone production $(120.5 \pm 10.3 \%, 117.5 \pm 13.0 \%)$. The mean value of progesterone secretion was 2.05 and $2.00 \mathrm{ng} / \mathrm{ml}$, whereas in untreated (control) group $1.70 \mathrm{ng} / \mathrm{ml}$ progesterone was recorded. In the remaining doses, a gradual decrease without significant changes was 

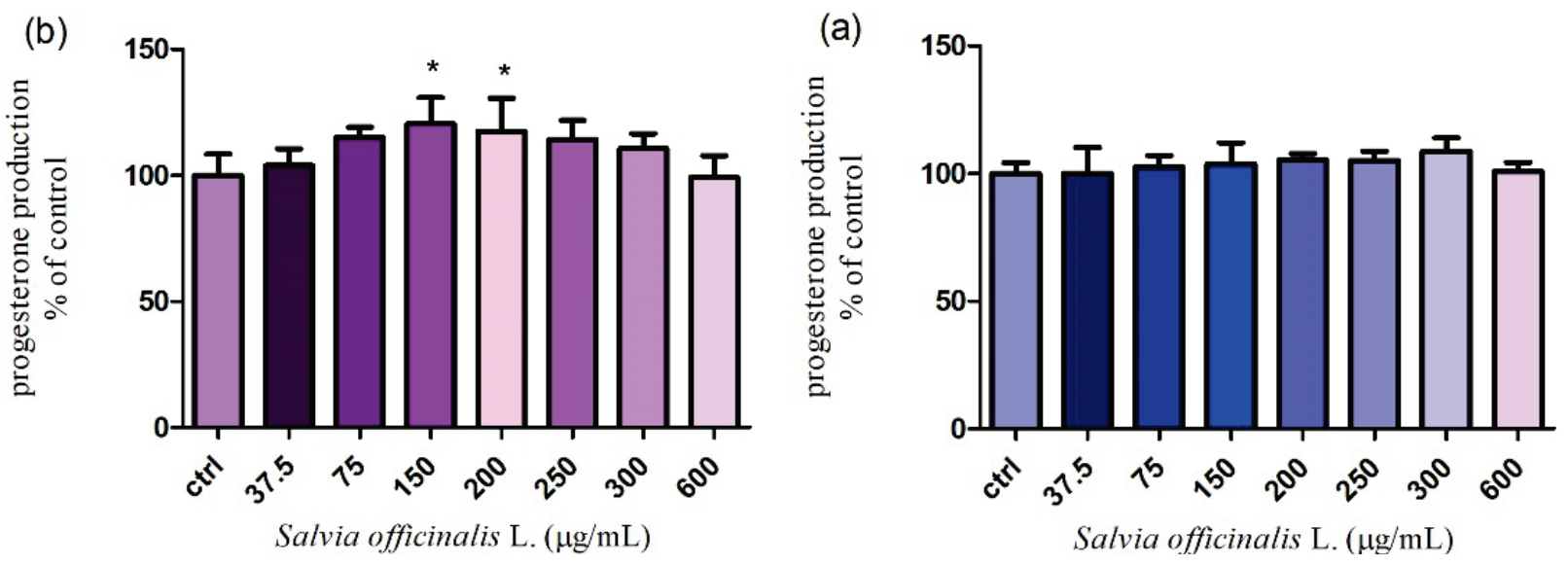

Fig. 5. Progesterone production in TM3 Leydig cells treated with different concentrations of Salvia officinalis L. for (a) $24 \mathrm{~h}$ and (b) $48 \mathrm{~h}$ cultivation. Abbreviations: ctrl - control group. Each bar represents the mean ( \pm S.D.) progesterone \% of control (untreated) and treated groups. Data were obtained from four $(n=4)$ independent experiments. The level of significance was set at $*(P<0.05)$. Statistical differences between the values of control experimental groups is indicated by an asterisk. (colorless)

(b)

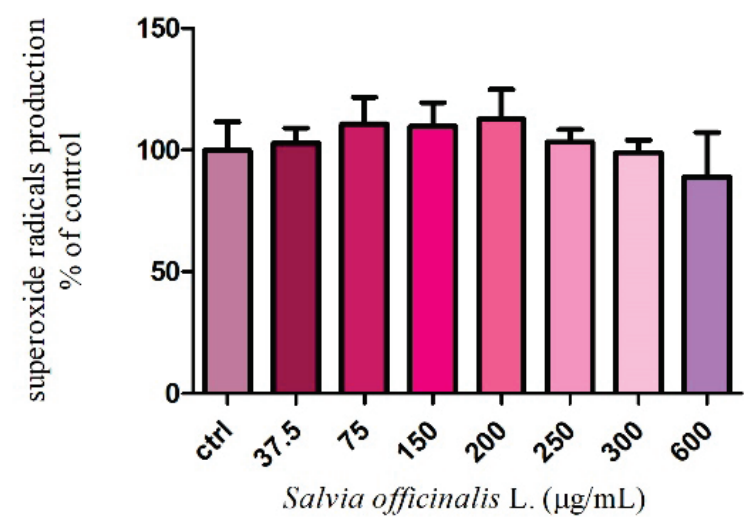

(a)

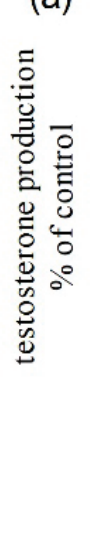

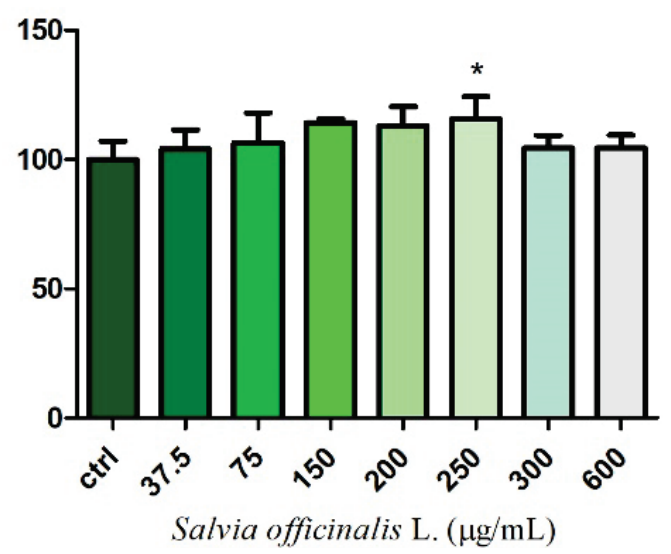

Fig. 6. Testosterone production in TM3 Leydig cells treated with different concentrations of Salvia officinalis L. for (a) $24 \mathrm{~h}$ and (b) $48 \mathrm{~h}$ cultivation. Abbreviations: ctrl - control group. Each bar represents the mean ( \pm S.D.) testosterone $\%$ of control (untreated) and treated groups. Data were obtained from four $(n=4)$ independent experiments. The level of significance was set at $*(P<0.05)$. Statistical differences between the values of control experimental groups is indicated by an asterisk. (colorless)

observed. As seen in Figure 6a., the tested extract caused a progressive increase in the testosterone production up to $200 \mu \mathrm{g} / \mathrm{ml}$, followed by a significant $(P<0.05)$ stimulation at $250 \mu \mathrm{g} / \mathrm{ml}(115.8 \pm 8.4 \%$ respectively $2.44 \mathrm{ng} / \mathrm{ml}$ ) after $24 \mathrm{~h}$ treatment. A similar tendency was confirmed after $48 \mathrm{~h}$ incubation. We found that the concentrations of Salvia officinalis L. (200, 250 and $300 \mu \mathrm{g} / \mathrm{ml})$ significantly $(P<0.05) \quad$ stimulated the testosterone secretion (119.9 $\pm 9.2 \% \quad 123.0 \pm 7.3 \%$ and $121.0 \pm 5.4 \%$ ). The mean values varied from $1.90 \mathrm{ng} / \mathrm{ml}$ to $1.97 \mathrm{ng} / \mathrm{ml}$. All applied concentrations were compared with the control cells $(1.42 \mathrm{ng} / \mathrm{ml})$ (Fig. 6b.). According to the obtained results, we may suppose that the higher applied doses positively affected the steroidogenic process essential for normal reproductive functions.

\section{Measurement of reactive oxygen species (ROS)}

It turned out that the previous fundamental parameters were not markedly damaged. Therefore, we wanted to study if either Salvia officinalis L. stimulates or inhibits the intracellular production of ROS after $24 \mathrm{~h}$ and $48 \mathrm{~h}$ cultivation. According to the nitroblue-tetrazolium assay, none of the applied doses $(37.5-600 \mu \mathrm{g} / \mathrm{ml})$ significantly affected the superoxide radicals released after $24 \mathrm{~h}$ incubation. However, treatment with the highest concentration $(600 \mu \mathrm{g} / \mathrm{ml})$ led to a progressive decrease $(86.5 \pm 5.0 \%)$ in the ROS production without significant changes $(P>0.05)$ in comparison to the control group $(100.0 \pm 4.8 \%)$ (Fig. 7a.). The extended time of cultivation showed similar results. As shown in Figure $7 \mathrm{~b}$. a reduced generation of superoxide radicals $(89.1 \pm 7.3 \%)$ was recorded only in case of the highest 
dose of the tested extract. All data were compared to the untreated cells $(100.0 \pm 4.7 \%)$. The experimental data suggest that the chosen doses of Salvia officinalis L. had a weak antioxidative potential and did not negatively affect all presented parameters. (b)

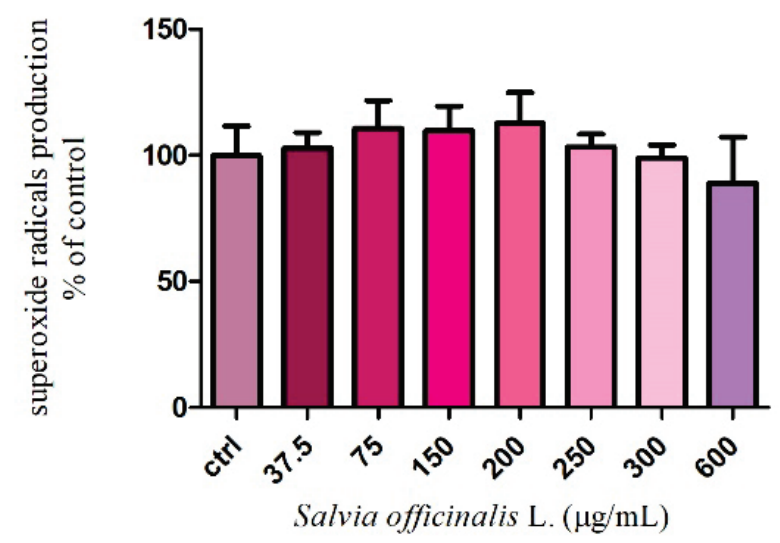

(a)

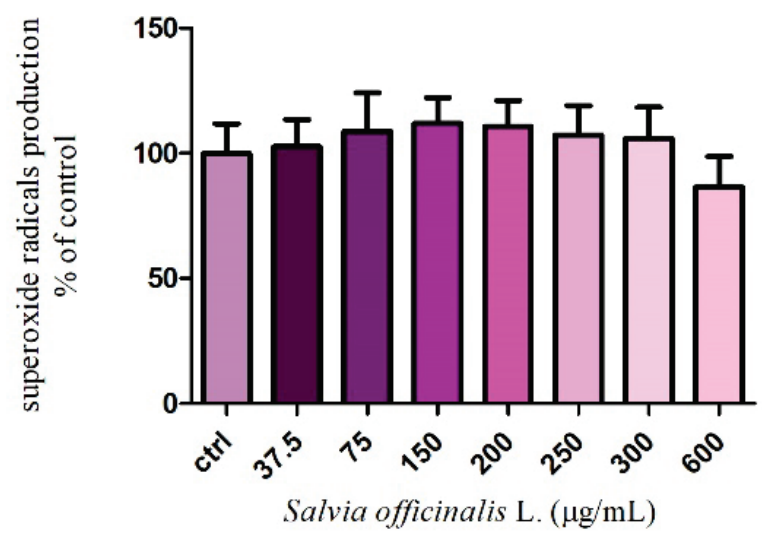

Fig. 7. The intracellular formation of superoxide radicals in TM3 Leydig cells treated with different concentrations of Salvia officinalis L. for (a) $24 \mathrm{~h}$ and (b) $48 \mathrm{~h}$ cultivation. Abbreviations: ctrl - control group. Each bar represents the mean ( \pm S.D.) free radical \% of control (untreated) and treated groups. Data were obtained from four $(n=4)$ independent experiments. The level of significance was set at $*(P<0.05)$. Statistical differences between the values of control experimental groups is indicated by an asterisk. (colorless)

\section{Discussion}

In our study, we investigated the in vitro effect of Salvia officinalis L. extract on selected essential cellular processes running in TM3 Leydig cells. We confirmed, that some of the tested concentrations may positively affect steroidogenesis without negative consequences on the cell viability and membrane integrity together with ROS scavenging activity in a dose- and time- dependent nature. Salvia officinalis L. is characterized by the presence of numerous bioactive phytoconstituents such as flavonoids, phenolic acids, tannins, terpenoids, and other secondary metabolites. The results of our HPLC-DAD analysis confirmed higher amounts of cynaroside $(41.9 \mathrm{mg} / \mathrm{kg})$, rutin $(39.1 \mathrm{mg} / \mathrm{kg})$ and kaempferol (38.0 $\mathrm{mg} / \mathrm{kg})$, followed by apigenin, daidzein, quercetin or resveratrol. Furthermore, total phenolics content of the tested extract was found to be $7855.68 \pm 59.92 \mathrm{mg} / \mathrm{kg}$ when compared with the gallic acid equivalent. The estimation of the radical scavenging effect performed by DPPH assay demonstrates $90.07 \pm 4.01 \%$ inhibition of the stable DPPH free radical. Adbelkader et al. (2014) studied the extract from leaves of Salvia officinalis L. by simple chemical tests and showed the presence of flavonoids (quercetin, caffeic acid), triterpenoids and steroids ( $\beta$-sitosterol, $\beta$-amirin) as well as cinnamic derivatives (chlorgenic acid). Results from the colorimetric analysis focused on the total phenolic content $(31.15 \pm 1.05 \mathrm{mg} / \mathrm{g}$ GAE) and DPPH radical scavenging activity $(130.56 \pm 0.86 \%)$ confirmed a strong antioxidant activity of this plant extract. Kosar et al. (2010) determined the quantitative and qualitative content of phytochemicals in the Salvia officinalis leaves by HPLC analysis. A number of components could not be identified. However, their chemical class was tentatively determined. The major component was rosmarinic acid, followed by luteolin-7-O-glycoside, luteolin and caffeic acid. The authors also confirmed a significant scavenging DPPH property in a concentration dependency. They were convinced that abietane diterpenes and rosmarinic acid were responsible for the potent scavenging activity of the Salvia taxa.

Many experimental studies confirmed antimicrobial, anti-inflammatory or anti-carcinogenic properties of Salvia species. Furthermore, Salvia species have been reported to improve male reproductive functions, however current information about the exact mechanism and specific effects are limited. According to our results, a prolonged time of cultivation significantly increased the viability of TM3 Leydig cells at $200 \mu \mathrm{g} / \mathrm{ml}$. Overleaf, at the highest concentrations $(600 \mu \mathrm{g} / \mathrm{ml})$ a progressive decline was observed. In addition, during the evaluation of the cell membrane integrity, essential for the sufficient activity of steroidogenesis, we did not confirm any significant damage of the membrane continuity after $24 \mathrm{~h}$ or $48 \mathrm{~h}$. A recent study determined 
the protective in vivo effect of Salvia officinalis L. extract on the rat's testis. Experimental animals were exposed to diazinon $(200 \mathrm{mg} / \mathrm{kg})$ and daily treated by Salvia officinalis L. (100 mg/kg) for four weeks. The results confirmed, that rats with diazinon exhibited a decreased number of spermatogonia, spermatocytes, Leydig and Sertoli cells. On the other hand, data obtained from rats treated by diazinon together with the tested extract confirmed the protective effect of Salvia in possible tissue damage. The amount of Leydig cells, sperm cells, Sertoli cells as well as diameter of seminiferous tubules were positively affected (Fattahi and Vaseghi, 2015). The irreversible damage in the cell viability in vitro induced by Salvia officinalis L. were investigated by Lima et al. (2004). Hepatocytes isolated from rat liver were cultured in the presence of an essential oil from Salvia $(2-2000 \mathrm{nl} / \mathrm{ml})$ for $30 \mathrm{~min}$. The results showed that the tested oil was not toxic when present at concentrations below $200 \mathrm{nl} / \mathrm{ml}$. Progressive changes were recorded at $2000 \mathrm{nl} / \mathrm{ml}$, where a significant LDH leakage and GSH decrease were observed indicating cell damage. Cell viability assay was performed on FL83B mouse hepatocytes by Chen et al. (2019) in vitro. Experimental cells were treated with 200,500 and $1000 \mu \mathrm{g} / \mathrm{ml}$ of tea extract from Salvia officinalis L. leaves for $24 \mathrm{~h}$. The tested extract at 200 and $500 \mu \mathrm{g} / \mathrm{ml}$ had no significant effects on the growth of mouse hepatocytes. However, treatment with the highest dose significantly reduced the cell viability. The improving effects of Salvia on male reproductive system may come from the effect of Salvia phytoconstituents, specifically rosmarinic acid, quercetin, kaempferol, rutin, thujone, rosmanol and many others. The potential impact of rutin on Leydig cell viability was evaluated by Sun et al. (2017). TM3 cells were treated by rutin at 10, 20 and $40 \mu \mathrm{mol} / \mathrm{L}$ during $12 \mathrm{~h}, 24$ and $48 \mathrm{~h}$. As the results showed, the cell viability did not significantly differ among the groups, whit different concentrations and time courses. Chen et al. (2007) monitored whether quercetin and resveratrol may affect tumor Leydig cell proliferation in different time periods in vitro. The results of the study did not confirm any cytotoxic effect. The experimental concentrations $(0.5-50 \mu \mathrm{M})$ had no significant effects after a five-day exposure. Although the in vitro effects of Salvia officinalis L. on Leydig cells have not been entirely documented, many reports investigated a significant impact on the spermatogenesis, testosterone production, and erectile functions (Jasem et al. 2010, Alzweiri et al. 2011, Ismail et al. 2013).
Results of our in vitro study demonstrate, that some experimental concentrations of Salvia officinalis L. extract may progressively enhance the production of steroid hormones. Especially, a significant increase in the testosterone production was confirmed at $250 \mu \mathrm{g} / \mathrm{ml} \mathrm{after}$ $24 \mathrm{~h}$ cultivation, followed by a significant rise in the testosterone release at 200, 250 and $300 \mu \mathrm{g} / \mathrm{ml}$ for $48 \mathrm{~h}$. Progesterone secretion was significantly enhanced at 150 and $200 \mu \mathrm{g} / \mathrm{ml}$ after $48 \mathrm{~h}$ of exposition. Bahr and Ibrahim (2015) performed a study focused on the examination of hydroalcoholic leaves extract from Salvia officinalis L. on the testosterone levels and testicular tissue changes in male rats. In rats fed with 150 and $200 \mathrm{mg} / \mathrm{kg}$ a significant increase in the serum testosterone levels and seminiferous tubule diameter as well as number of spermatozoa was observed. Salah et al. (2016) monitored the effect of Salvia officinalis L. $(300 \mathrm{mg} / \mathrm{kg}$ body weight) on the testosterone production in albino male rats after five weeks of treatment. Compared with the non-treated rats, the level of testosterone was significantly increased together with $\mathrm{LH}$ and follicle stimulating hormone (FSH). We have compared our data with a few in vitro studies focusing on the potential impact of bioactive constituents occurring in Salvia officinalis L. extracts on the steroid hormone production by Leydig cells. A recent study determined the effects of resveratrol and quercetin $\left(\begin{array}{llll}1 & - & 50 & \mu \mathrm{M}\end{array}\right)$ on the steroidogenesis in MA-10 Leydig cells. Progesterone production was significantly decreased by resveratrol at 25 and $50 \mu \mathrm{M}$ after $24 \mathrm{~h}$ cultivation. An opposite tendency was recorded after quercetin treatment. The same experimental doses progressively increased progesterone release, only the highest concertation stimulated hormone production significantly. Resveratrol inhibited progesterone secretion through down-regulation of StAR gene expression at the transcriptional and mRNA levels. Inversely, quercetin stimulated hormone secretion by up-regualtion of StAR promoter activity and mRNA expression (Chen et al. 2007). To further information, the effect of rutin on the testosterone release in mice Leydig cells was examined. The results confirmed an increased steroid hormone production in a dose-dependency. A significant growth was observed at 20 and $40 \mu \mathrm{mol} / \mathrm{L}$ of rutin after a $24 \mathrm{~h}$ incubation (Sun et al. 2017). A further in vitro study determined the effect of kaempferol from Alcea rosea $(1 \mu \mathrm{g} / \mathrm{ml})$ on isolated rats Leydig cells. Radioimmunological analysis of steroid hormone production revealed a significantly higher level of testosterone in the control group than in the 
experimental cells after a $24 \mathrm{~h}$ cultivation (Papiez et al. 2002). All of the presented results suggested that there are differential effects of phytoconstituents on Leydig cells functions. As such, there is a necessity to favor and evaluate parallel effects of a wide range of bioactive compounds collectively before focusing on individual actions. On the contrary, in vitro studies support our present finding, where lower doses have no significant impact on Leydig cell functions, while high concentrations may negatively affect the cell viability or steroidogenesis.

The evaluation of superoxide radical production in our study did not confirm any significant impact. Some of the tested concentrations slightly increased the superoxide production, however higher doses $(250-600 \mu \mathrm{g} / \mathrm{ml})$ gradually scavenged these radicals regardless of cultivation time. We assume, that a prolonged incubation with Salvia may support the protection against oxidative stress. Consistent with our study, Frei and Higdon (2003) reported that Salvia officinalis L. effectively scavenged free radicals and modulated the antioxidant pathways. This may be due to its phytoconstituent, namely, rosmarinic acid which protects membrane lipids against oxidative insults. Fattahi and Vaseghi (2015) indicate that the extract of Salvia officinalis L. inhibits the production of free radicals and repair tissues thereby minimizing cell damage caused by excessive free radicals. Zupko et al. (2001) showed that various Salvia officinalis species have an inhibitory effect on the lipid peroxidation induced by $\mathrm{Cu}^{2+}$ - and $\mathrm{Fe}^{2+}$-containing compound that have free radical scavenging activities. A recent study reported that Salvia officinalis L. tea consumption may improve the lipid profile inducing a decrease of the highly atherogenic LDL-C particles, which are rapidly oxidable. It follows that phytoconstituents of Salvia may protect essential components of cellular membranes and prevent irreversible changes to the molecular mechanisms as well as viability damage (Elida et al. 2010). Sun et al. (2017) reported that some experimental concentrations $(10,20$ and $40 \mu \mathrm{mol} / \mathrm{L})$ of rutin decreased ROS generation and malondialdehyde (MDA) levels in TM3 Leydig cells after a $24 \mathrm{~h}$ cultivation. Additionally, the activities of antioxidant enzymes, especially superoxide dismutase (SOD), catalase (CAT) or peroxidase (POD) were remarkably increased by rutin at 20 and $40 \mu \mathrm{mol} / \mathrm{L}$. According to a previous in vitro study, the extract from Salvia officinalis L. may affect the antioxidant status of Caco-2 cell line. This experimental model was treated by
$60 \mu \mathrm{g} / \mathrm{ml}$ of $S$. officinalis L. during $24 \mathrm{~h}$. The cellular content of reduced glutathione (GSH) was significantly increased when compared with the control group. In the contrary, no significant differences in the SOD and CAT activity were observed. In addition, the same experimental concentration has not induced single-strand DNA breaks investigated by the comet assay after a $24 \mathrm{~h}$ exposition (Aherne et al. 2007). Apparently, the unique composition of Salvia officinalis L. leads to the regulation of signal transduction pathways of cell growth and proliferation, induction of apoptosis, modulation of enzymatic activity related to the secretion of steroid hormones as well as to the regulation of hormone metabolism. Our data highly emphasize on the need to further evaluate the exact effects of phytoconstituents present in Salvia officinalis L. extract on the in vitro cellular parameters or processes running in Leydig cells.

\section{Conclusion}

Herbal medicines derived from plant extracts are being increasingly utilized to treat a wide variety of human diseases. The current in vitro study highlights the potential beneficial effects of Salvia officinalis L. that may be linked to its antioxidant properties and efficiency to affect cellular functions of exposed TM3 Leydig cell line. Experimental doses of Salvia revealed a dose- and time-dependent stimulation of the cell viability and steroid hormone production. What is more, none of the experimental doses significantly damaged the membrane integrity, and the production of reactive oxygen species has not been significantly affected. In view of these in vitro observations, we assume that a balanced concertation ratio may support the Leydig cell function, steroidogenesis as well as viability, which may significantly improve reproductive performance in males.

\section{Highlights}

- $\quad$ Only the highest dose of Salvia officinalis L. decreased cell viability significantly

- Cell membrane integrity was not significantly affected by Salvia officinalis L.

- $\quad 150$ and $200 \mu \mathrm{g} / \mathrm{ml}$ of Salvia significantly increased progesterone production

- $\quad$ Significant stimulation of testosterone release was recorded at 200; 250 and $300 \mu \mathrm{g} / \mathrm{ml}$

- $\quad$ ROS scavenging activity of Salvia was observed without significant changes 


\section{Conflict of Interest}

There is no conflict of interest.

\section{Acknowledgements}

This work was financially supported by the Slovak Research and Development Agency Grant no. APVV-160289, APVV-15-0543 and Scientific Agency of the Slovak Republic VEGA No. 1/0038/19.

\section{References}

ABDELKADER M, AHCEN B, RACHID D, HAKIN H: Phytochemical study and biological activity of sage (Salvia officinalis L.). Int J Life Sci Biotechnol 8: 1253-1257, 2014. https://doi.org/10.5281/zenodo.1326832

AHERNE SA, KERRY JP, O'BREIN NM: Effects of plant extracts on antioxidant status and oxidant-induced strass in Caco-2 cells. Br J Nutr 97: 321-328, 2007. https://doi.org/10.1017/S0007114507250469

ALZWEIRI M, AL SARHAN A, MANSI K, HUDAIB, M, ABURJAI T: Ethnopharmacological survey of medicinal herbs in Jordan, the northern badia region. J Ethnopharmacol 137: 27-35, 2011. https://doi.org/10.1016/j.jep.2011.02.007

BAHR HI, IBRAHIM AE: Phytopreventive effect of Salvia officinalis L. on infertility induced by hypothyroidism in male albino rats. Biomedical 4: 40-44, 2015.

CHEN GW, CHEN TY, YANG PM: Differential effect of herbal tea extracts on free fatty acids-, ethanol- and acetaminophen-induced hepatotoxicity in FL83B hepatocytes. Drug Chem Toxicol 17: 1-6, 2019. https://doi.org/10.1080/01480545.2019.1692026

CHEN YCH, NAGPAL ML, STOCCO DM, LIN T: Effects of genistein, resveratrol, and quercetin o steroidogenesis and proliferation of MA-10 mouse Leydig tumor cells. J Endocrinol 192: 527-537, 2007. https://doi.org/10.1677/JOE-06-0087

CHOI HS, KIM JQ, CHA YN, KIM C: A quantitative nitroblue tetrazolium assay for determining intracellular superoxide anion production in phagocytic cells. J Immunoassay Immunochem 27: 31-44, 2006. https://doi.org/10.1080/15321810500403722

ELIDA B, DANIEL Z, PAYAL P, VISHAL J, TEJAS L, INNA K, SIDNEY J, SIDHARTHA D: A novel dietary supplement containing multiple phytochemicals and vitamins elevates hepatorenal and cardiac antioxidant enzymes in the absence of significant serum chemistry and genomic changes. Oxid Med Cell Longev 3 : 129-144, 2010. https://doi.org/10.4161/oxim.3.2.11157

ESMAEILI MA, SONBOLI A, KANNANI MR, SADEGHI H: Salvia sahendica prevents tissue damages induced by alcohol in oxidative stress conditions. Effect on liver and kidney oxidative parameters. J Med Plants Res 3: 276-283, 2009.

FATTAHI E, VASEGHI M: Protective effect of salvia officinalis on testes tissue damages of rats intoxicated by diazinon. JMPB 1: 39-43, 2015.

FREI B, HIGDON JV: Antioxidant activity of tea polyphenols in vivo: evidence from animal studies. J Nutr 133: 3275-3284, 2003. https://doi.org/10.1093/jn/133.10.3275S

HALO JR M, MASSANYI P, GREN A, LASAK A, SLANINA T, ONDRUSKA L, MUCHACKA R, GALBAVY D, IVANIC P, SCHNEIR R, FORMICKI G: Time and dose-dependent effect of Viscum album quercus on rabbit spermatozoa motility and viability in vitro. Physiol Res 68: 955-972, 2019. https://doi.org/10.33549/physiolres.934223

ISMAIL BH, HAMMED SM: Effect of Salvia officinalis on the histological parameters and physiological criteria of male reproductive system in mice. J Vet Sci 6: 157-162, 2013.

JAMBOR T, KOVACIKOVA E, GREIFOVA H, KOVACIK A, LIBOVA L, LUKAC N: Assessment of the effective impact of bisphenols on mitochondrial activity and steroidogenesis a dose-dependency in mice TM3 Leydig cells. Physiol Res 4: 689-693, 2019. https://doi.org/10.33549/physiolres.934200

JASEM E, NASIM J, GHOLAMREZA M, NASER S, NABER M, MARYAM, SL, ABBAS N, VAHID R: Evaluation of the effects of Salvia hypoleuca on the cAMP-responsive element modulator (CREM) gene expression and spermatogenesis in rat. Mid East Fertility Society J 15: 274-277, 2010. https://doi.org/10.1016/j.mefs.2010.08.002 
KOSAR M, DORMAN HJ, BASER KH, HILLTUNEN R: Salvia officinalis L.: composition and antioxidant-related activities of a crude extract and selected sub-fractions. Natur Product Com 5: 1453-1456, 2010. https://doi.org/10.1177/1934578X1000500921

KOVACIK A, TIRPAK F, TOMKA M, MISKEJE M, TVRDA E, ARVAY, J, ANDREJI J, SLANINA T, GABOR M, HLEBA L, FIK M, JAMBOR T, CISAROVA M, MASSANYI P: Trace elements content in semen and their interactions with sperm quality and Red Ox status in freshwater fish Cyprinus carpio: A correlation study. J Trace Elem Med Biol 50: 399-407, 2018. https://doi.org/10.1016/j.jtemb.2018.08.005

LIMA CF, CARVALHO F, FARNANDES E, BASTOS ML, SANTOS-GOMES PC, FARNANDES-FERREIRA M, PEREIRA-WILSON C: Evaluation of toxic/protective effects of $t$ essential oil of Salvia officinalis on freshly isolated rat hepatocytes. Toxicol In Vitro 18: 457-465, 2004. https://doi.org/10.1016/j.tiv.2004.01.001

LUKŠIČ L, ÁRVAY J, VOLLMANNOVÁ A, TÓTH T, SKRABANIA V, TRČEK J, GERM M, KREFT I: Hydrothermal treatment of Tartary buckwheat grain hinders the transudation of rutin to quercetin. J Cereal Sci 72: 131-134, 2016. https://doi.org/10.1016/j.jcs.2016.10.009

MOSMANN T: Rapid colorimetric assay for cellular growth and survival. Application to proliferation and cytotoxicity assays. J Immunol Methods 16: 55-63, 1983. https://doi.org/10.1016/0022-1759(83)90303-4

PAPIEZ M, GANCARCZYK M, BILINSKA B: The compounds form the hollyhock extract (Althaea rosea Cav. Var. nigra) affect the aromatization in rat testicular cells in vivo and in vitro. Folia Histochem Cytobiol 40: 353-359, 2002.

RAHTE S, EVANS R, EUGSTER PJ, MARCOURT L, WOLFENDER JL, KORTENKAMP A, TASDEMIR D: Salvia officinalis for hot flushes. Towards determination of mechanism of activity and active principles. Planta Med 79: 753-760, 2013. https://doi.org/10.1055/s-0032-1328552

SAHA R, ROYCHODHURY S, KAR K, VARGHESE AC, NANDI P, SHARMA GD, FORMICKI G, SLAMA P, KOLESAROVA A: Coenzyme Q10 ameliorates cadmium induced reproductive toxicity in male rats. Physiol Res 68: 141-145, 2019. https://doi.org/10.33549/physiolres.934000

SALAH MM, HUSSEIN MS, MAHMOOD R, KHALID LB: Effect of Salvia officinalis L (sage) aqueous extract on liver and testicular function of diabetic albino male rats. J Univ Babylon 24: 390-399, 2016.

SÁNCHÉZ-MORENO C, LARRAURI A, SAURA-CALIXTO F: A procedure to measure the antioxidant efficiency of polyphenols. J Sci Food Agricul 76: 270-276, 1998. https://doi.org/10.1002/(SICI)10970010(199802)76:2<270::AID-JSFA945>3.0.CO,2-9

SCHEER A, TINSON C, SHERRY JP, SHCHRIMER K: Application of alamar blue/5carboxylfluorescein diacetate acetoxymethyl ester as a noninvasive cell viability assay in primary hepatocytes from rainbow trout. Anal Biochem 344: 76-85, 2005. https://doi.org/10.1016/j.ab.2005.06.009

SINGH S, LI SS: Epigenetic effects of environmental chemicals bisphenol A and phthalates. Int J Mol Sci 13: 10143-10153, 2012. https://doi.org/10.3390/ijms130810143

SINGLEOTN VL, ROSSI JA: Colorimetry of total phenolics with phosphomolybdic-phosphotungstic acid reagents. Am J Enol Viticul 6: 1444-1458, 1965.

SULTAN C, BALAGUER P, TEROUANNE B, GEORGET V, PARIS F, JEANDEL C, NICOLAS J: Environmental xenoestrogens, antiandrogens and disorders of male sexual differentiation. Mol Cell Endocrinol 178: 99-105, 2001. https://doi.org/10.1016/S0303-7207(01)00430-0

SUN J, WANG H, LIU B, SHI W, SHI J, ZHANG Z, XING J: Rutin attenuates H2O2 - induced oxidation damage and apoptosis in Leydig cells by activating PI3K/Akt signal pathways. Biomed Pharmacother 88: 500-506, 2017. https://doi.org/10.1016/j.biopha.2017.01.066

TOHAMY AA, IBRAHIM SR, MONEIM AEA: Studies on the effect of Salvia aegyptiaca and Trigonella foenum graecum extracts on adult male mice. JAPS 2: 36-43, 2012. https://doi.org/10.7324/JAPS.2012.2501

TVRDÁ E, BOTMAN B, HALENÁR M, SLANINA T, LUKÁČ N: In vitro effects of Salvia officinalis on bovine spermatozoa. Int J Biol Biomol Agricul Food Biotechnol Engineering 11: 89-95, 2017.

WANG Y, CHEN F, YE L, ZIRKIN B, CHEN H: Steroidogenesis in Leydig cells: effects of aging and environmental factors. Reproduction 154: 111-122, 2017. https://doi.org/10.1530/REP-17-0064 
ZUPKO I, HOHMANN J, REDEI D, FALKAY G, JANISCAK G, MATHE I: Antioxidant activity of leaves of Salvia species in enzyme-dependent and enzyme-independent systems of lipid peroxidation and their phenolic constituents. Planta Medica 67: 366-368, 2001. https://doi.org/10.1055/s-2001-14327 